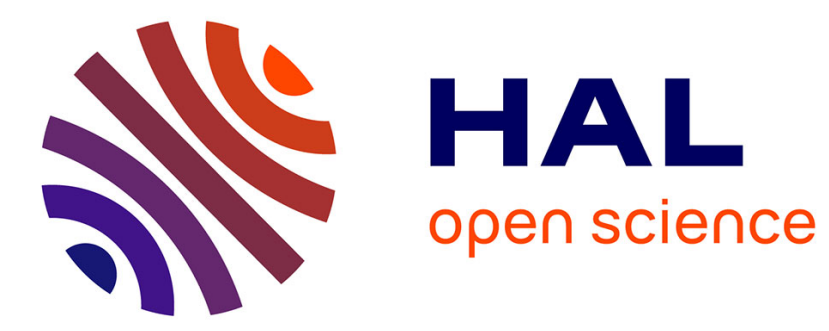

\title{
Grapevine and climatic changes: a glance at the situation in Alsace
}

Eric Duchêne, Christophe Schneider

\section{To cite this version:}

Eric Duchêne, Christophe Schneider. Grapevine and climatic changes: a glance at the situation in Alsace. Agronomy for Sustainable Development, 2005, 25 (1), pp.93-99. 10.1051/agro:2004057 . hal-02682113

\section{HAL Id: hal-02682113 \\ https://hal.inrae.fr/hal-02682113}

Submitted on 1 Jun 2020

HAL is a multi-disciplinary open access archive for the deposit and dissemination of scientific research documents, whether they are published or not. The documents may come from teaching and research institutions in France or abroad, or from public or private research centers.
L'archive ouverte pluridisciplinaire HAL, est destinée au dépôt et à la diffusion de documents scientifiques de niveau recherche, publiés ou non, émanant des établissements d'enseignement et de recherche français ou étrangers, des laboratoires publics ou privés. 


\title{
Grapevine and climatic changes: a glance at the situation in Alsace
}

\author{
Eric DUCHÊNE*, Christophe SCHNEIDER \\ Unité Mixte de Recherche INRA-Université Louis Pasteur “Santé de la Vigne et Qualité du Vin”, 28 rue de Herrlisheim, BP 507, 68021 Colmar Cedex, France
}

(Received 15 January 2004; accepted 7 October 2004)

\begin{abstract}
The analysis of meteorological data recorded since 1972 at the INRA Station in Colmar (Alsace, France) reveals a significant increase in temperatures. Phenological data recorded on INRA grapevine collections over the same period show that the period between budburst and harvest has become both earlier and shorter. A comparison of climatic and phenological data shows that ripening is occuring under increasingly warm conditions. The climatic water demand after flowering tends to increase and, as there is no clear evidence for a change in rainfall, the risks associated with dry summers are likely to increase in the future. Quantified data on climate evolution, development stages and bioclimatic indices during the main development phases are presented and discussed.
\end{abstract}

Vitis vinifera / climate change / development stages / Alsace

\section{INTRODUCTION}

The changes in climatic conditions on earth, including global warming, are no longer contested. As documented in the last issue of the report of the Intergovernmental Panel on Climate Change (IPCC), prepared under the aegis of the United Nations Environment Program (UNEP) and the World Meteorological Organization (WMO), the average global temperature has increased by $0.6{ }^{\circ} \mathrm{C}$ during the 20th century and the last decade is "very likely" to prove the warmest since meteorological data have been recorded [12]. This evolution is well explained by an increase in the concentrations of greenhouse gases in the atmosphere, i.e. an annual increase in carbon dioxide concentration $\left(\mathrm{CO}_{2}\right)$ of $1.5 \mathrm{ppm}$ from 1980 to 2000. Similar trends are observed for methane $\left(\mathrm{CH}_{4}\right)$ and nitrous oxide $\left(\mathrm{N}_{2} \mathrm{O}\right)$ [12]. The accumulation of these gases is related to human activities and $\mathrm{CO}_{2}$ concentrations of 540 to $970 \mathrm{ppm}$ are predicted for 2100 , together with an increase in the global average temperature on the earth's surface of 1.4 to $5.8^{\circ} \mathrm{C}$ [12]. These climatic changes have, and will continue to have, effects on living organisms and human activities such as agriculture.

The present study aims at

(i) assessing whether the climate over the vine-growing region of Alsace has changed over the last 30 years and which parameters have been affected;

(ii) evaluating the potential consequences on grapevine physiology; (iii) anticipating the adjustments the local grape industry will have to make to face the new challenges.

\section{MATERIALS AND METHODS}

The meteorological data recorded since 1972 at the INRA Station in Colmar ( $\left.48^{\circ} 03^{\prime} \mathrm{N}, 7^{\circ} 19^{\prime} \mathrm{E}\right)$ were used in this study, as well as rainfall data since 1949 . All data were provided by Météo France and were completed for solar radiation for the period before 1990 by data from the INRA STEFCLI database.

Phenological observations were recorded in ampelographic collections in the INRA vineyard at Bergheim, located $20 \mathrm{~km}$ north of Colmar. These data were made available to the "PhénoClim" database of the INRA Station in Avignon [10]. Our study focused on the Vitis vinifera $c v$. Riesling, a representative variety of the Alsatian grape industry. Because ampelographic collections in Bergheim were being renewed from 1972 to 1975, phenological data were obtained from other vineyards for these 4 years.

The development cycle of the grapevine can be divided into three major phases:

(1) From budburst to flowering, the vegetative organs and floral parts develop. The reserves built up during the previous growing season are mobilized by the plant for the start of spring growth and the vegetative apparatus gradually becomes autotrophic. The flowering period

\footnotetext{
* Corresponding author: duchene@ colmar.inra.fr
} 
is considered as a transition phase, since the plant starts at this time to accumulate new reserves.

(2) From flowering to véraison, the plant actively accumulates biomass. The vegetative development has become sufficient and is controlled by hedging operations. Berries are actively growing through cell division and enlargement, but stay green and hard.

(3) From véraison to harvest, the vegetative growth slows down, berries become priority sinks, start to soften, undergo color change and begin to accumulate large amounts of sugars while the acid content decreases. The ripening process of the grapes takes place.

Visual observations are the usual means to determine the dates for the budburst-flowering and flowering-véraison phases. Budburst, flowering and véraison dates correspond in our case to " $50 \%$ of buds at the C stage according to Baggiolini" [1], " $50 \%$ of open flowers" and " $50 \%$ of soft berries", respectively. We delimited the ripening period as "véraison-véraison+35 days", so that the final date calculated for each year was consistent with the official vintage opening date in the Alsace vine-growing area.

Several criteria were chosen to characterize the functioning of the vine.

The minimum temperature for grapevine physiological activity is commonly estimated to be $10{ }^{\circ} \mathrm{C}[26,27]$. The main phases of the development cycle were characterized with heat summations above $10{ }^{\circ} \mathrm{C}$ :

Heat summation $=\sum_{i=1, n} \operatorname{Max}\left(0.5\left(\mathrm{~T}_{\min , \mathrm{i}}+\mathrm{T}_{\text {max }, \mathrm{i}}\right)-10 ; 0\right)$

where $\mathrm{T}_{\min }$ and $\mathrm{T}_{\max }$ are, respectively, the minimum and maximum daily temperature, $n$ the number of days of the period and "Max" the mathematical function "maximum".

The Huglin index (HI) [13] gives a greater weight to maximum temperatures. It is calculated from April to September and allows a good assessment to be made of the year to year variability, as well as a prediction of the suitability of a variety in a given area:

$$
H I=\sum_{i=01.04}^{i=30.09} K\left[\frac{\left(\mathrm{T}_{\text {mean }, \mathrm{i}}-10\right)+\left(\mathrm{T}_{\text {max }, \mathrm{i}}-10\right)}{2}\right]
$$

where $\mathrm{T}_{\text {mean }}$ is the mean daily temperature and $K$ a coefficient depending on latitude; $K$ equals 1.06 for Colmar.

The ability of the grapevine to accumulate biomass was estimated according to the model proposed by Bindi et al. [5]. This model takes into account the leaf area, the global solar radiation and the minimum and maximum temperatures. It calculates, on a daily basis, the biomass increase per $\mathrm{m}^{2}$. Although not validated for Riesling in the environment of Alsace, we consider it is adequate to assess the year to year variability of vine behavior, in relation to climatic conditions. However, we do not claim that the calculated values correspond to the reality. This model was used only after flowering, when solar radiation interception has almost reached its maximum. We calculated a potential biomass accumulation (PBA) as:

$$
P B A=\sum_{i=1, n} M S(i)
$$

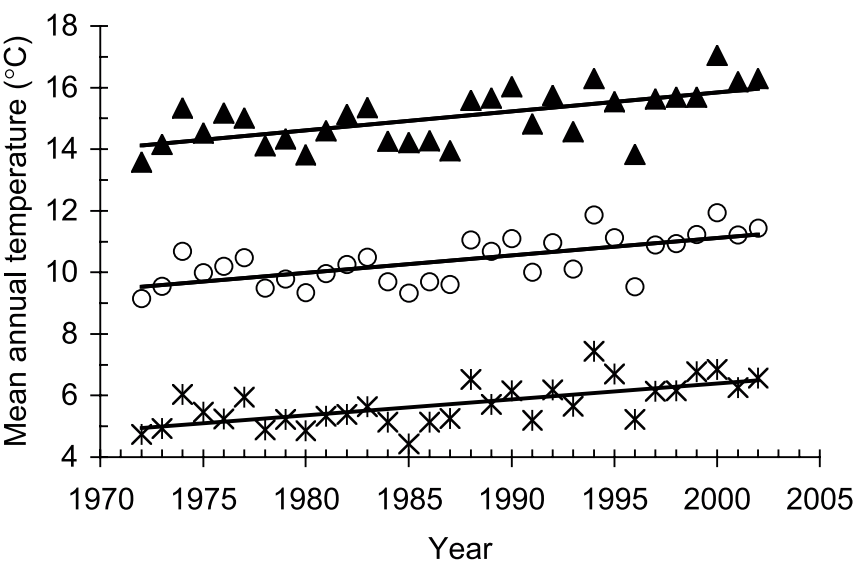

\section{* minimumo mean $\Delta$ maximum}

Figure 1. Evolution of the mean annual temperatures in Colmar. The trend is about $0.06{ }^{\circ} \mathrm{C}$ per annum for the maximum temperatures, $0.05^{\circ} \mathrm{C}$ per annum for the minimum temperatures.

where $M S(i)$ is the function giving the daily biomass increase according to the previously described model and $n$ the number of days in the period.

Each of the above-mentioned bioclimatic indices, as well as weather parameters, were plotted against a timescale in years, and a trend was calculated.

In each case, a Spearman $\rho$ coefficient was calculated to evaluate the statistical significance of the observed trend [20, 24]. This coefficient can be used to test a correlation of rank and is calculated as:

$$
\rho=1-\frac{6 \sum_{i=1, n}\left(y_{i}-i\right)^{2}}{n\left(n^{2}-1\right)}
$$

where $i$ is the chronological rank of the year, $y_{i}$ its rank when the annual values for the considered criterion are arranged in ascending order and $n$ the number of years in the series. The $\rho$ coefficient varies between -1 and +1 . A nil value means that there is no relationship between the two rankings. A Student test was used to decide whether or not the $\rho$ value was significantly different from 0 . Hereafter in this text, we shall refer to the $p$ probability, first kind error associated with the test of the hypothesis $\rho=0$.

\section{RESULTS AND DISCUSSION}

\subsection{Weather parameters and bioclimatic indices}

Annual average temperature data has shown a tendency to increase since 1972 (Fig. 1). The average trend is about $0.06{ }^{\circ} \mathrm{C}$ per annum; that is almost $2^{\circ} \mathrm{C}$ over 30 years, and the $\rho$ coefficient is highly significant $(P<0.001)$. These values are comparable with the greatest increase predicted in the IPCC scenarios for the coming years. This increase is apparent in every season but is particularly marked in spring (Tab. I). It is 
Table I. Evolution of the average temperatures between 1972 and 2002 in Colmar.

\begin{tabular}{lccccccccc}
\hline & \multicolumn{2}{c}{ Spring } & \multicolumn{2}{c}{ Summer } & \multicolumn{2}{c}{ Fall } & \multicolumn{2}{c}{ Winter } \\
\hline Parameter & T min & T max & T min & T max & T min & T max & T min & T max \\
\hline Increase in ${ }^{\circ} \mathrm{C}$ per annum & 0.06 & 0.08 & 0.04 & 0.07 & 0.05 & 0.03 & 0.05 & 0.06 \\
Spearman coefficient & 0.55 & 0.61 & 0.54 & 0.54 & 0.40 & 0.43 & 0.36 & 0.40 \\
$P$ & 0.001 & $<0.001$ & 0.002 & 0.002 & 0.02 & 0.02 & 0.05 & 0.03 \\
\hline
\end{tabular}

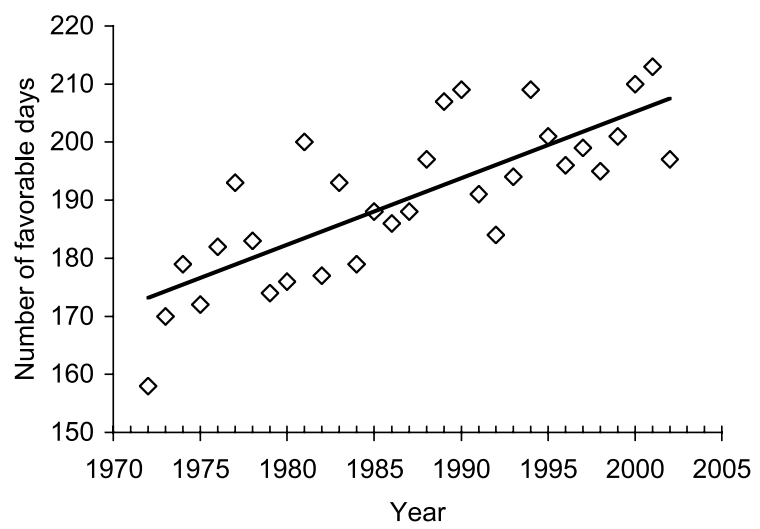

Figure 2. Evolution of the number of days with a mean daily temperature above $10{ }^{\circ} \mathrm{C}$ during the calendar year in Colmar. The trend is +1.1 days per annum.

only in fall that the increase is greater for minimum than for maximum temperatures.

The number of days favorable to vine activity (mean temperature above $10^{\circ} \mathrm{C}$ ) have increased by more than one day per annum $(P<0.001)$ (Fig. 2$)$, both at the beginning of the development cycle, in April $(P=0.004)$, and at the end of the cycle, in October $(P=0.004)$. The vegetative cycle was therefore potentially extended.

The heat summation above $10^{\circ} \mathrm{C}$ and the Huglin index, observed from April to September, when most of the vegetative growth occurs, have clearly increased $(P<0.001$ for both parameters; Fig. 3).

The annual precipitations since 1972 have not changed noticeably $(P=0.45)$, although 1999 and 2002 were the wettest years during the period. A very weak trend ( $+2 \mathrm{~mm}$ per annum) is detectable $(P=0.05)$ when data since 1949 are included.

As observed in France and in most parts of the world, the increase in the temperatures recorded at the INRA Station in Colmar during the past thirty years is highly significant. This increase is particularly marked from the middle $80 \mathrm{~s}$, about $0.06{ }^{\circ} \mathrm{C}$ per annum, which is substantially higher than the $0.7^{\circ} \mathrm{C}$ per century observed by Moisselin et al. [20] for the East of France. Our study is based solely on data from one station and over a restricted period of time during which the temperature evolution was rapid, as shown by the long-term records at Paris-Montsouris, for example [20]. Except in fall, we did not find a trend for a greater increase in minimum as compared with maximum temperatures. These results are different from those

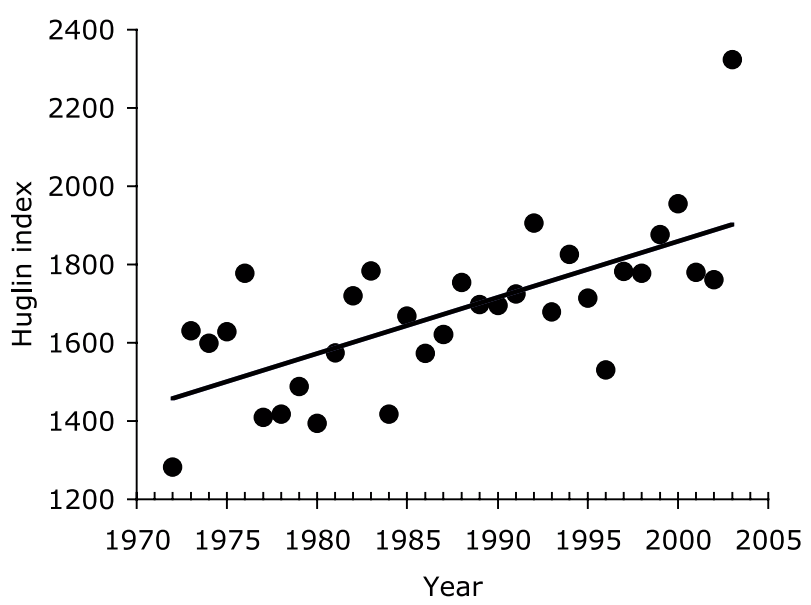

Figure 3. Evolution of the Huglin index in Colmar. The trend is about +14.3 degree-days per annum including 2003 , about +11.6 degreedays per annum without 2003. These data relate only to the April-September period.

observed on the scale of a century [20] and predicted by the IPCC scenarios [12], where the miminum temperatures tend to increase more rapidly that the maximum ones.

Once it is admitted that the changes in temperature will continue, then, on the basis of a North-South variation in mean temperature of $+0.5^{\circ} \mathrm{C}$ for $100 \mathrm{~km}$ [20], Colmar would have a temperature profile equivalent to the latitude of Lyon in 2030, and to the latitude of Montpellier in 2060.

The effects of the global increase in temperatures are clearly visible on the phenological data from the INRA vineyard at Bergheim.

\subsection{Phenology and harvest dates}

Budburst, flowering and véraison dates have clearly changed (Fig. 4). Budburst and flowering dates were approximately 15 days earlier in 2003 compared with $1965(P=0.002$ and $P=0.006$, respectively). The forwardness of the véraison stage, almost 23 days over the same period $(P<0.001)$, resulted from both an earlier budburst and a reduction, of approximately 8 days, in the flowering-véraison period $(P=0.03)$. However, when data since 1958 are analyzed for budburst, the Spearman coefficient is no longer significant $(P=0.11)$. As suggested by some data sets $[12,20]$, the $60 \mathrm{~s}-70$ s period was rather cold and could have amplified some trends. 

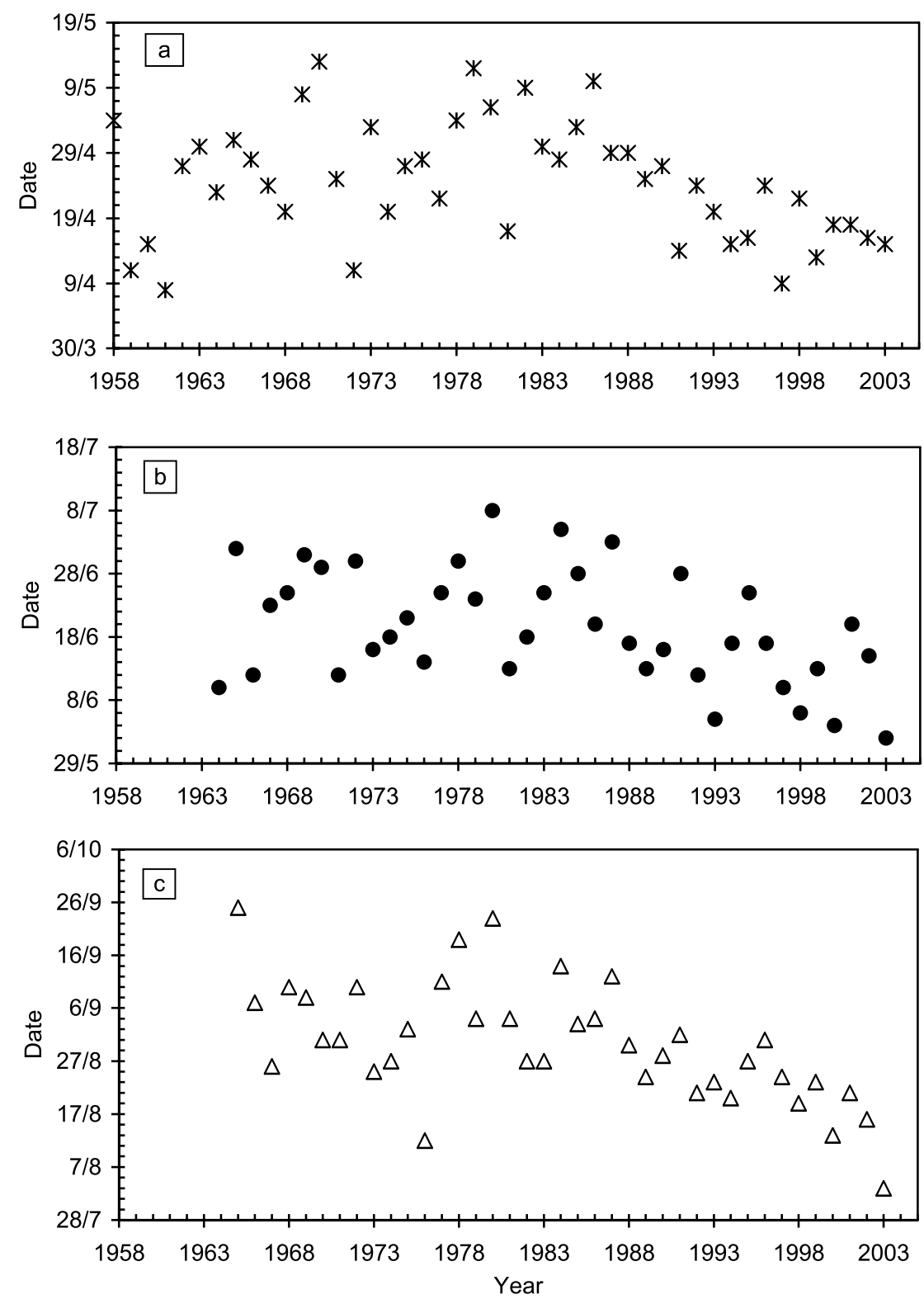

Figure 4. Budburst (a), flowering (b) and véraison (c) dates for Riesling in Bergheim (68). INRA data.

Consequently, the vintage opening dates became earlier (Fig. 5). Although this trend is globally significant $(P=0.006)$ for the period since 1950, we can distinguish a phase with a progressive delay in the dates between 1950 and $1980(P=0.04)$ followed by a strikingly reversed tendency since $1980(P<$ 0.001).

As the post-harvest period for the current varieties tends to be more and more favorable to plant activity, new varieties of vines may be adapted to the future environmental conditions. Taking the average current Huglin index in Alsace at 1800 degree-days, the annual increase at 14 degree-days (Fig. 3) and the figures suggested by Huglin [13], then the cultivation of Cabernet-Franc (1800 degree-days) should already be possible in Alsace, the cultivation of Cabernet-Sauvignon, Chenin blanc and Merlot (1900 degree-days) could be expected for 2010, and Grenache and Syrah (2100 degree-days) for 2025.

\subsection{Effects of climatic conditions during the main phases of the vegetative cycle}

We attempted to evaluate the effects of the observed changes in the grapevine phenology on its functioning. Complete phenological records exist for Bergheim since 1965 but meteorological data are available for this site only since 1987, whereas the data for Colmar exist since 1972. Despite some distance between Bergheim and Colmar (about $20 \mathrm{~km}$ ), the coefficient 


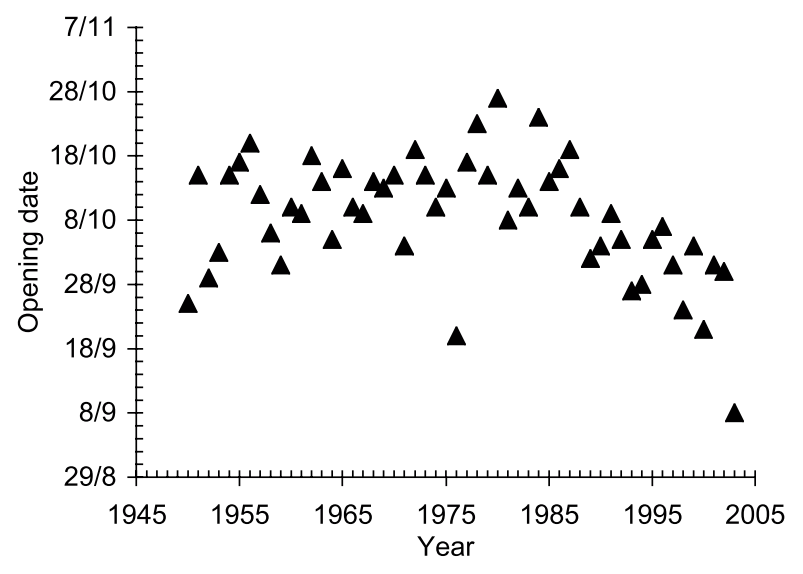

Figure 5. Vintage opening dates for the Alsace vine-growing area (Riesling). INAO data.

of determination, $\mathrm{R}^{2}$, between the mean daily temperatures of the two sites from 1987 to 2002 is higher than 0.98 . We therefore considered that the approximations made by combining phenological data from Bergheim and meteorological data from Colmar were slight with respect to the main climatic trends.

For the budburst-flowering, flowering-véraison and ripening periods, we calculated the average minimum, maximum and mean temperatures, the heat summation (Eq. (1)), precipitation $(\mathrm{P})$, potential evapotranspiration (ETP), P-ETP, solar radiation and potential biomass accumulation (Eq. (3)).

During the budburst-flowering phase, no clear tendency was noticeable for any of these criteria.

In contrast, the flowering-véraison phase tended to shorten by about 1 day every five years. The sum of active temperatures over this period increased slightly in parallel with an increase of $0.05{ }^{\circ} \mathrm{C}(P=0.02)$ and $0.08{ }^{\circ} \mathrm{C}(P=0.01)$ per annum for the minimum and maximum temperatures, respectively (data not shown).

A shorter flowering-véraison period should reduce the total amount of solar radiation intercepted during this phase. No significant trend was observed $(P=0.81$, Fig. 6$)$ partly because, in the range of the observations, the day length was on average longer with earlier flowering. As to the potential biomass accumulation, higher temperatures and $\mathrm{CO}_{2}$ concentrations increase the photosynthetic activity rate. According to Bindi et al. [3], the photosynthesis rate increases by $0.15 \%$ per annum with a $1.5 \mathrm{ppm}$ per annum increase in $\mathrm{CO}_{2}$ content. In conclusion, the theoretical potential biomass production over this period was not modified (Fig. 6).

The increase in ETP over this period was significant $(P=0.008)$ and led to a higher P-ETP deficit $(P=0.03)$.

The most spectacular effects were observed during the ripening period of the grapes. The mean temperature gain was approximately $0.15^{\circ} \mathrm{C}$ per annum $(P<0.01)$; that is, $4.5^{\circ} \mathrm{C}$ in 30 years (Fig. 7). The temperature increase in August and September, approximately $0.05{ }^{\circ} \mathrm{C}$ per annum, was not significant ( $P=0.06$ for the mean daily temperature). The observed changes can therefore mainly be attributed to the earlier véraison dates.

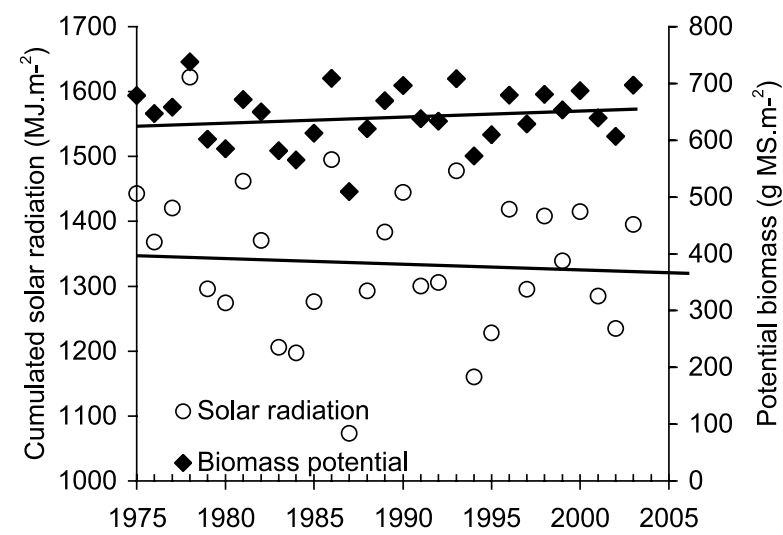

Figure 6. Solar radiation and potential biomass production during the flowering-véraison period. Phenological data for Riesling, INRA in Bergheim. Meteorological data: Météo France Colmar.

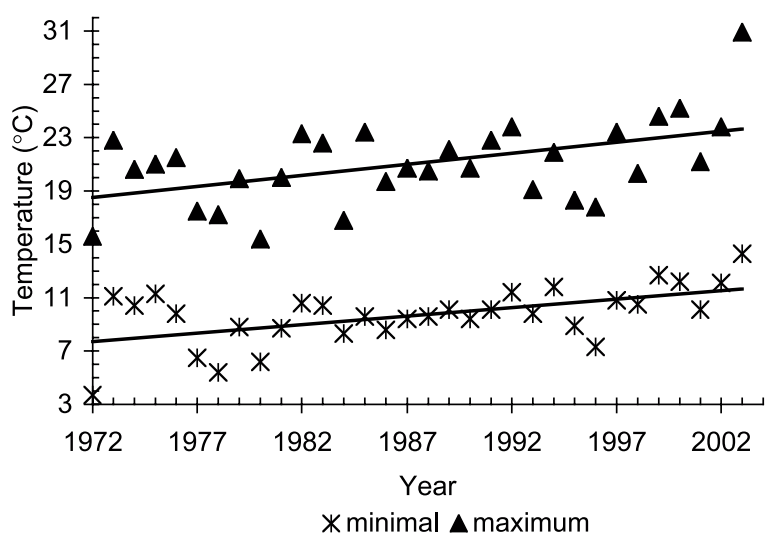

Figure 7. Evolution of the mean temperatures during the ripening phase. The trend is $+0.17^{\circ} \mathrm{C}$ per annum for maximum temperatures, $+0.13{ }^{\circ} \mathrm{C}$ per annum for minimum temperatures. Without 2003, these trends are $+0.12{ }^{\circ} \mathrm{C}$ and $+0.11^{\circ} \mathrm{C}$, respectively.

The heat summation also increased, at a rate of 4.7 degree-days per annum $(P=0.008)$, as well as the potential biomass production $(P=0.03)$. The corollary of these increases was a higher climatic water demand ETP $(P=0.002)$. These more favorable ripening conditions were undoubtedly largely responsible for the higher $(P<0.001)$ levels of potential alcohol observed at vintage time (Fig. 8).

We have already shown [11] that earlier harvest dates, combined with more favorable post-harvest periods, theoretically increase the post-harvest biomass accumulation and thus improve the grapevine's ability to accumulate reserves for the following season.

It is a delicate point to appreciate the effect of climate changes on total biomass production. Photosynthesis [22] and thus biomass production react positively to increased $\mathrm{CO}_{2}$ concentrations up to $550 \mathrm{ppm}$ [4]. In the two years of experiments reported by Bindi et al. [4], fruit yield evolved more or less in 


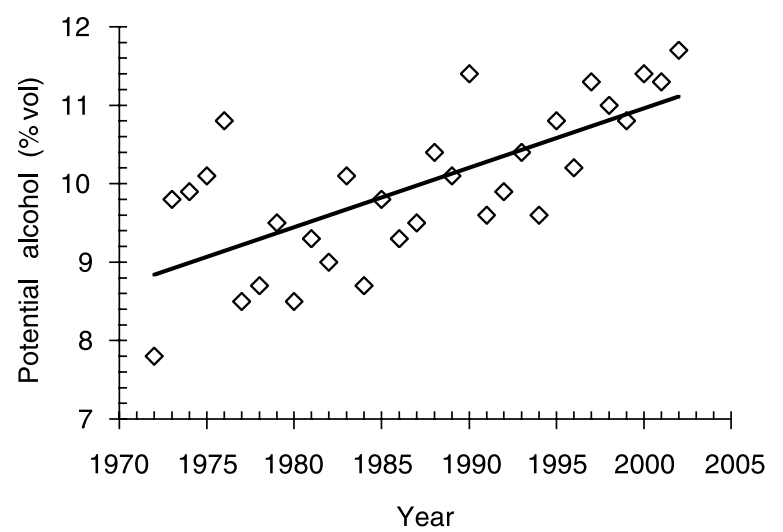

Figure 8. Evolution of potential alcohol levels at harvest for Riesling in Alsace. The trend is $0.08 \%$ vol. per annum. Data source: CIVA.

parallel with total biomass production. By using different scenarios of climate change, but without taking into account the water availability, these authors predicted a higher but more variable biomass production [3]. On the one hand, higher temperatures shorten the development cycle, but on the other, the photosynthesis rate is improved both by this increase in mean temperatures and by higher $\mathrm{CO}_{2}$ concentration. The effects on yield simulated by these authors are less clear and depend on the scenario applied. More generally, yield depends on the vegetative/reproductive balance and undoubtedly on the balance between nitrogen and carbohydrates. Current models do not integrate these elements. It is, however, extremely probable that with longer cycles, favorable to the formation of reserves [11], yields will tend to increase, unless spring frosts cause more damage as a result of earlier budburst.

Our discussion has so far been based on the assumption that water supply will not be a limiting factor. Even if on a world scale or over a year the total rainfall amounts should increase [12], their distribution in time and space is very uncertain. Winter rainfall is expected to increase as well as the risk of summer dryness on the continents [12]. Moreover, the current models do not allow work on a local scale and Moisselin et al. [20] have shown that the tendencies for precipitations during the 20th century were not the same everywhere in France. We have no clear indication of what will be the precipitation levels during the vegetative period of the vine in Alsace. The projected increase in biomass production is thus very unreliable even if a higher $\mathrm{CO}_{2}$ concentration in the air leads to a better water use efficiency [22]. Means to limit water demand, or to increase water supply, should be considered. Increasing water availability would rely, to begin with, on a reduction of the grass cover when used in the vineyards. This can be in contradiction with the need to prevent any erosion due to periods of more intense precipitations. Modifying the canopy structure, through reduced plant density or reduced foliage heights, would be another way to limit water demand.

Whatever the yield level, grape quality is strongly dependent on temperature conditions during the ripening period. Temperature influences the breakdown of acids $[8,15]$ and the berry coloration $[8,16,17]$ and seems to affect the secondary metabolite content of the grapes.
Terpenols are among the molecules that form part of the typicity of Alsatian wines. A good grape exposure enhances the accumulation of these molecules [2, 21], but past experiments did not distinguish between the effect of solar radiation and the effect of temperatures. Belancic et al. [2] suggested that too high temperatures can have negative effects on the terpenol content. In the results reported by Bureau et al. [7], higher levels of bound or free terpenols were observed in the grapes shaded by the leaves in comparison with those which were artificially shaded. The solar radiation reaching the berries being similar in both cases, the differences could be explained by higher temperatures in the artificially shaded bunches. In addition, it has been empirically noticed that cool conditions are preferable for the development of aromatic characters [6, 14, 21, 25].

The accumulation of terpenols is probably maximized over a certain range of temperatures, with too low or too high temperatures having a negative effect. It would be necessary to characterize this range better and to test the possible effects of the forecast climatic scenarios. Presumably, not all the varieties will have the same sensitivity to temperature variations, as has been shown for berry coloration [17].

In addition, 1,1,6-trimethyl-1,2-dihydronaphthalene (TDN) is an important compound of Riesling, giving it a mineral, even sometimes "kerosene" character $[19,23]$. Some carotenoids appear to be the precursors of this molecule and it has been shown [19] that the carotenoid content is higher when conditions are warmer. It is for this reason that Marais [18] recommends Riesling should be grown in cool areas.

If higher temperatures initially improve ripening and thus lead to better quality wine, in the long term, with a continuous increase, they could result in a change in the aromatic profile of wines produced in Alsace and elsewhere. The exceptionally warm and early growing season in 2003 is an experience on a large scale of what could become normal conditions. It should therefore be informative in anticipating aromatic profiles which can be expected to develop in the future.

\section{CONCLUSION}

Significant increases in temperature have been recorded during the past thirty years at the INRA Station in Colmar, which is representative of the Alsace vine-growing area. The period between budburst and harvest has been both brought forward and shortened. Maturation has occurred under increasingly warm conditions. This evolution seems inescapable; it is likely to continue and even to accelerate.

There is no clear trend for rainfall. The increase in temperature and $\mathrm{CO}_{2}$ concentration in the air for the years to come should lead to a stronger climatic potential for biomass production, requiring an increased water supply. Even if an improvement of the water use efficiency can be expected, the fear remains of greater water stress.

These likely changes in environmental conditions will necessitate some adjustments to preserve certain specific characteristics of the wines produced in Alsace.

The choice of the plant material is the first key to adaptation. Within rootstocks, there is a genetic variability for induced precocity [9], and for tolerance to dry conditions [14]. For the 
scion-variety, there is also a broad range of variation for precocity, ability to maintain a certain acidity under hot conditions and tolerance to dry conditions [14].

Training systems, in a broad sense, from soil management to canopy architecture, will undoubtedly also have to be modified, especially if dry summers become a reality.

Lastly, new areas, at higher altitudes, for example, should be considered since they might be suited to the production of good quality wines.

For the first time for more than one thousand years, the climate of tomorrow will certainly not resemble that of today. The certainties are very few, except for an increase in temperatures. What will be the water availability? What will be the risk of spring frost damage? How will pressure from pests and diseases evolve? Not since the phylloxera crises has there been such a need for the wine industry to review its strategies and techniques in the years ahead.

Acknowledgments: to Météo France Colmar, to the "Institut National des Appellations d'Origine" (INAO) Colmar and to the "Comité Interprofessionnel des Vins d'Alsace" (CIVA) for their contribution to the data sets. Special thanks to Beryl Edwards for English language advice.

\section{REFERENCES}

[1] Baggiolini M., Les stades repères dans le développement annuel de la vigne et leur utilisation pratique, Rev. Rom. Agr. Viticult. 8 (1952) 4-6.

[2] Belancic A., Agosin E., Ibacache A., Bordeu E., Baumes R.L., Razungles A.J., Bayonove C.L., Influence of sun exposure on the aromatic composition of chilean muscat grape cultivars Moscatel de Alejandria and Moscatel Rosada, Am. J. Enol. Viticult. 48 (1997) 181-185.

[3] Bindi M., Fibbi L., Gozzini B., Orlandini S., Miglietta F., Modelling the impact of future climate scenarios on yield and yield variability of grapevine, Climate Res. 7 (1996) 213-224.

[4] Bindi M., Fibbi L., Miglietta F., Free Air $\mathrm{CO}_{2}$ Enrichment (FACE) of grapevine (Vitis vinifera L.): II. Growth and quality of grape and wine in response to elevated $\mathrm{CO}_{2}$ concentrations, Eur. J. Agron. 14 (2001) 145-155.

[5] Bindi M., Miglietta F., Gozzini B., Orlandini S., Seghi L., A simple model for simulation of growth and development in grapevine (Vitis vinifera L.). I. Model description, Vitis 36 (1997) 67-71.

[6] Borsa D., Barbagallo M.G., di Lorenzo R., di Stefano R., Terpenes compounds changes of Sicily "Italia" grapes during ripening according to cultivation environment and covering by nets, Riv. Viticolt. Enol. 55 (2002) 23-38.

[7] Bureau S.M., Razungles A.J., Baumes R.L., The aroma of Musca of Frontignan grapes: effect of the light environment of vine or bunch on volatiles and glycoconjugates, J. Sci. Food Agr. 80 (2000) 2012-2020.

[8] Buttrose M.S., Hale C.R., Kliewer W.M., Effect of temperature on the composition of "Cabernet-Sauvignon" berries, Am. J. Enol. Viticult. 22 (1971) 71-75.
[9] Cordeau J., Création d'un vignoble. Greffage de la vigne et portegreffes. Élimination des maladies à virus, Editions Féret, 1998.

[10] Domergue M., Seguin B., Baculat B., Legave J.M., Brisson N., Suivre l'impact du climat sur les arbres fruitiers et la vigne. La base de données Phénoclim, INRA Mensuel 116 (2003) 12-16.

[11] Duchêne E., Effets des conditions de maturation des raisins sur les composantes du rendement au cours des années suivantes, Les Vins d'Alsace octobre (2003) 12-15.

[12] GIEC, Bilan 2001 des changements climatiques : Les éléments scientifiques, OMM-PNUE, 2001.

[13] Huglin P., Nouveau mode d'évaluation des possibilités héliothermiques d'un milieu viticole, C.R. Acad. Agric. (1978) 1117-1126.

[14] Huglin P., Schneider C., Biologie et Écologie de la Vigne, Lavoisier Tec et Doc., 1998

[15] Kliewer W.M., Effect of day temperature and light intensity on concentration of malic and tartaric acids in V. vinifera grapes, J. Am. Soc. Horticult. Sci. 96 (1971) 372-377.

[16] Kliewer W.M., Influence of temperature, solar radiation and nitrogen on coloration and composition of emperor-grapes, Am. J. Enol Viticult. 28 (1977) 96-103.

[17] Kliewer W.M., Torres R.E., Effect of controlled day and night temperatures on grape coloration, Am. J. Enol. Viticult. 23 (1972) 71-77.

[18] Marais J., Factors affecting the development of 1,1,6-trimethyl-1,2dihydronaphatalene in Riesling grapes and wine, Connaissance Aromatique des cépages et qualité des vins, 9-10 février 1993, Montpellier, France, p. 5.

[19] Marais J., van Wyk C.J., Rapp A., Carotenoids levels in maturing grapes as affected by climate regions, sunlight and shade, S. Afr. J. Enol. Viticult. 12 (1991) 64-69.

[20] Moisselin J.M., Schneider M., Canellas C., Mestre O., Les changements climatiques en France au $\mathrm{XX}^{\mathrm{e}}$ siècle. Etude de longues séries homogénéisées de données de température et de précipitations, La Météorologie 38 (2002) 45-56.

[21] Reynolds A.G., Wardle D.A., Significance of viticultural and enological practices on monoterpenes flavorants of British Columbiagrown Vitis vinifera berries and juices, Viticult. Enol. Sci. 48 (1993) 194-202.

[22] Schultz H.R., Climate change and viticulture: A European perspective on climatology, carbon dioxide and UV-B effects, Aust. J. Grape Wine Res. 6 (2000) 2-12.

[23] Simpson R.F., Miller G.C., Aroma composition of aged Riesling wine, Vitis 22 (1983) 51-63.

[24] Snedecor G.W., Cochran W.G., Méthodes statistiques, ACTA, 1957.

[25] Tonietto J., Carbonneau A., Facteurs mésoclimatiques de la typicité du raisin de table de l'A.O.C. Muscat du Ventoux dans le département de Vaucluse, France, Prog. Agric. Viticult. 115 (1998) $271-$ 279.

[26] Williams D.W., Andris H.L., Beede R.H., Luvisi D.A., Norton M.V.K., Williams L.E., Validation of a model for the growth and development of the Thompson Seedless grapevine. II. Phenology, Am. J. Enol. Viticult. 36 (1985) 283-289.

[27] Winkler A.J., Cook J.A., Kliewer W.M., Lider L.A., General Viticulture, University of California Press, 1974. 